\title{
CHINESE ON THE MINING FRONTIER IN SOUTHEAST ASIA
}

\author{
Anthony Reid
}

The influx of Chinese into Malaysia in particular and "Central Southeast Asia" more generally is often popularly attributed to colonial rule, as if the pluralism they exemplified were not "natural" to the region. In reality, the Peninsula has always been highly plural, and the advance of the Chinese mining frontier within it preceded the British. ${ }^{1}$ This essay documents some of the means by which Chinese mining advanced the economic frontiers in Southeast Asia ahead of European capital. Tin, being the most obvious example, takes center stage in this story.

\section{Early Controversies}

How metals technology spread in Southeast Asia in the earliest periods is a matter of considerable and long-standing debate, particularly since the Ban Chiang excavations in Thailand in the 1970s raised the possibility that bronze-working there may have been as old as that in China. The earliest Ban Chiang periodizations have now been largely discredited, however, and a consensus is emerging that the Southeast Asian bronze age began in the middle of the second century B.C.E., that it was distinct from any of the older "Chinese" traditions, yet somehow related to them, and that it long pre-dated the rise of states in Southeast Asia. Gold, iron, copper, and tin were undoubtedly mined, smelted, and worked into ornaments, utensils, and weapons in Southeast Asia before the Common Era (C.E.), and Chinese records of contact with Lao peoples at the end of the sixth century C.E. declare that they made their own bronze drums in a manner different from the Chinese. We know little, however, about how the relevant technologies were disseminated or developed. ${ }^{2}$

Until the era of bulk imports in the sixteenth and seventeenth centuries, iron and copper remained relatively scarce in island Southeast Asia, and trav- 
elers from Europe and China found that their everyday nails, knives, and needles were in great demand from the locals. The reasons appear to have been not so much the lack of minerals in the ground (although Java and Bali were particularly disadvantaged in that regard) as the sparse population (by Chinese standards) in the vicinity of most of these minerals, and consequently smaller scale, less efficient methods of both mining and smelting.

As trade developed in the second millennium of the Common Era, everyday metal items became cheaper to import from afar than to produce locally. In Sung times, iron and ironware were "among the commonest commodities" exported to Southeast Asia from China. ${ }^{3}$ By 1500 , the needs of Southeast Asian maritime centers like Melaka were provided principally from China, including "copper, iron . . . cast iron kettles, bowls, basins ... plenty of needles of a hundred different kinds, some of them very fine and well made ... and things of very poor quality like those that come to Portugal from Flanders." 4 These items could be produced far more cheaply in China than in any of the Southeast Asian cities because of more advanced mining and smelting methods, so that Southeast Asian mining and metalwork tended to retreat with time to less accessible areas in the interior.

\section{Was There a Chinese Role in Borneo Ironworking?}

Iron is found in the northerly areas of the mainland states, and in the hills between Siam and Burma, as well as in the islands in central Sumatra, Belitung, western Borneo, and central Sulawesi. Weapons, tools, and ploughtips manufactured in these places had to circulate to many other populous centers, such as Java and Bali, where iron was not found.

The ready availability of brown iron ores near the surface in many parts of western Borneo, and the islands of Belitung and Karimata off its shores, make this region particularly interesting. The ironworking site at the mouth of the Sarawak River was somewhat controversially investigated by Tom Harrison in the 1960 s. He and Stanley O'Connor claimed as many as 40,000 tons of slag were left behind in three adjacent sites where iron was extracted from ores between around 900 and 1350 . The technology for smelting the iron was not of Chinese type, with a fixed furnace, but rather by using open charcoal fires in bowl-like recessions in the ground. This relatively simple technology was still in use in the nineteenth century among peoples of interior Borneo such as the Kayan and Kenyah, whom imported iron was the last to reach. ${ }^{5}$ Karl Hutterer also found large amounts of slag in Cebu that he dated to ironsmelting processes of the thirteenth to fifteenth centuries. ${ }^{6}$

Both sites were relatively accessible to the China trade. In particular, West 
Borneo was on the standard sailing routes between south China and the Majapahit heartland of Java. While discounting Chinese technological influences on ironworking in Borneo, Harrison and O'Connor argue that Sarawak iron may have been carried to China by Arab and other ships, since too much was being produced for local consumption. Wheatley had already argued that wi-mung-i, which was listed in the Sung chronicle as being brought to China by Arab merchants, was probably "the hydrated iron oxide known as limonite." 7

Around 1600, a time for which evidence of the internal Southeast Asia trade is more abundant, the most important archipelago center for exporting parangs and other iron tools was Karimata, about 6 o kilometers off the coast of Southwest Borneo. Java and Makasar imported their axes and parangs from Karimata, while Malays of the Peninsula were said to carry krisses of Karimata steel. When the Dutch found a way to access this supply, in 1630, they purchased almost 10,000 axes and parangs in one lot. ${ }^{8}$ Although Belitung was also a source for this kind of trade, with "more parangs but fewer axes," the reputation of tiny Karimata for superior workmanship was such that the label "Karimata" was applied more widely. ${ }^{9}$

So centrally were the Karimata islands located on the sailing routes between China and Java that the major strait on that route was named the Karimata Strait, between those islands and Belitung. Whatever the case in the Sarawak River area, there is firm evidence in Karimata of Chinese craftsmen settling as early as the thirteenth century. Wang Dayuan, describing the Nanyang a half-century after the Mongol fleet set off to conquer Java in 1293, had this to say of an island he called Goulan Shan.

When the [Yuan] dynasty was founded, the forces to attack Java were driven by the wind to this island, and the ships wrecked. One ship fortunately escaped with stores of nails and mortar. Seeing that there was a great deal of timber on this island, they built some tens of ships, everything from ribs to sails and bamboo poles were supplied [from the island]. Over a hundred men who were ill from the long beating about in the storm and were unable to leave were left on the island, and today the Chinese live mixed up with the native families. ${ }^{10}$

Rockhill sought to identify this mysterious island with the tiny island of Gelam off the coast of Southwest Borneo, though the Karimata group seem more likely in view of their location on the sailing routes. Whether or not this group of Chinese transferred smelting technology to Karimata and Belitung, there were many other Chinese craftsmen who passed this way in 
Ming times, some of whom may also have been shipwrecked or defected voluntarily. As Zhou Daguan put it of Angkor in the 129os, since "women are easily had ... a great many sailors desert to take up permanent residence." 11

Whatever technology transfer there may have been to iron-production in this Karimata-Belitung area cannot have been continuous. The gap between economies of scale in production in China and in the archipelago grew wider with more frequent shipping in the seventeenth century. In the eighteenth century, cheaper imported Chinese iron- and metalwork drove out most of the production in accessible coastal areas of the archipelago. The dwindling community of ironworkers of Karimata left for the mainland in $1808 .{ }^{12}$

\section{Chinese Expansion of the Mining Frontier in the Eighteenth Century}

In the eighteenth century, China's population grew markedly, stimulating an increase in the demand for silver, gold, copper, and lead as currency to fuel the expanding economy. The quest for minerals was one factor propelling Chinese explorers, miners, traders, and officials south and west, eventually bringing the empire's extent to its historic maximum. Yunnan was the largest mining frontier for Chinese, with 300,000 Han miners reportedly working there in 1750 and 500,000 in $1800 .{ }^{13}$ Sources of silver, lead, and zinc were particularly abundant around what is today the boundary between southern Yunnan and Burma's Shan state. The massive Munai and Maolong mines peaked in production in the mid-eighteenth century, and eventually came under permanent Qing control. ${ }^{14}$ Chinese miners went beyond imperial control, into the hills in the north of Dai Viet and what is today Burmese and Lao territory.

The huge Bawdwin opencast mine in Shan territory was the most important Chinese-worked mine of the border area that never fell under Qing control. It may have been "protected" from this fate by malaria, which Herbert Hoover contracted when inspecting the mine for its modern rebirth in the British period. Ming records suggest that it was Chinese miners who first brought the mine into production in 1412, and they continued to extract silver from it in increasing amounts throughout the eighteenth century.

Copper, lead, and silver also occur in the northern border area of northern Vietnam, where geographical barriers to an influx of Chinese miners were less intimidating, but political ones were better established along one of Asia's oldest frontiers. Here, too, the eighteenth century was the peak period for the expansion of Chinese mining. The Trinh regime that governed northern Vietnam (Tonkin) profited greatly from the booming output of the mines 
and in the 1760 s was reportedly drawing half its revenue from levies on these northern mines. By midcentury, there were upward of 20,000 Cantonese at the Tong-tinh copper mines alone, despite a series of royal decrees seeking to limit their numbers. In the second half of the century, the copper-mining operation in the border areas was thought to have averaged over 500 tons output per annum, making it one of the largest in Asia. The tenuous control the court exercised over the Chinese mining kongsis caused increasing diffculties, however, and in 1767 the Trinh attempted to expel them from Vietnam. The economic stakes were too high, however, and the attempt failed. ${ }^{15}$

\section{Gold-Working}

Precious metals were the most ancient and valued of Southeast Asia's precious minerals, particularly the silver of the northern mainland close to Yunnan, and the gold of Sumatra, Borneo, and the Peninsula. Chinese miners were also attracted to these commodities, although they never became as dominant as they were on the nineteenth-century tin fields. Sumatran gold, which gave rise to the Sanskrit soubriquet Suvarna-bhumi (gold-land), was for the most part off limits to Chinese miners. It was considered so precious an item of royal monopoly that outsiders were discouraged. William Dampier related that in Aceh in the 168os, when gold had become the principal export of the state, only Muslims were permitted to go to the rich mining areas of Kawaj XIII in the hills behind Pidië. Huge profits were reportedly made in these gold fields, discovered only about thirty years earlier, and the wealth they produced brought Chinese traders and craftsmen to the Aceh capital every year. However, to prevent them reaching the goldfields, armed guards were posted along the route. ${ }^{16}$

Central Southeast Asia-western Borneo, eastern Sumatra and its islands, and the Peninsula - with its sparse populations and states largely dependent on the economic activities of outsiders, was the major Southeast Asian theater of Chinese mining. Gold had been extracted from Borneo and the Peninsula for more than a millennium, by simple methods of panning. However, as with tin, the larger-scale labor organization of Cantonese and Hakka miners was introduced to archipelago gold-mining in the middle of the eighteenth century. In most cases, river-mouth chiefs and rajas engaged them to work more efficiently interior mineral resources hitherto dependent on the part-time attention of agriculturalists.

One such early settlement on the Peninsula was Pulai, in upper Kelantan, which Hakka gold-miners had opened by the second half of the eighteenth 
century. ${ }^{17}$ Graham, however, suggests it was considerably older, and that in earlier times "the mineral products of Kelantan considerably exceeded in value those of any other State" in the Peninsula. ${ }^{18}$ During the reign of Sultan Mahmat in Kelantan (1807-1837), the ruler's son was killed by the previously self-governing Chinese miners when he tried to enforce his newly granted monopoly of rice distribution by cutting off the mining settlement from all supplies coming up the river to them. The dead prince's son then organized a massacre of the whole Chinese settlement, "and the gold mining industry of Kelantan came to a sudden end." 19

But it was the goldfields north of the Kapuas River in West Borneo that drew the largest number of Chinese pioneers. As early as 1740, the ruler of Mempawah, or in some accounts the Sultan of Sambas, decided to bring Chinese miners in to work the gold-bearing rivers he sought to control. Production had previously depended on the part-time labor of Dayaks. The Malay rulers used terms that had been effective on a small scale with the Dayaks, providing salt, rice, opium, and cloth at inflated monopoly prices in return for a monopoly of the gold extracted. In addition, the Chinese as outsiders were forbidden to engage in agriculture (to increase their dependence on the ruler's supplies) and were charged a head tax on entering or leaving Borneo through the ruler's port. ${ }^{20}$

The Chinese miners set to work initially on mines abandoned by the Dayaks, but used more intense and mechanized methods to sluice away the topsoil above the gold-bearing lode. They were also much more centrally organized through their kongsi, a ritual brotherhood in which capital and labor were shared in acknowledged portions. ${ }^{21}$ Gradually the kongsis became autonomous by forming their own relations with interior Dayaks (including marriage), farming the surrounding land, and smuggling their gold out through channels not controlled by the rulers. The capitalists who established the mine and funded the importation of workers of course had the largest share, and laborers still indebted for their passage had none, but older workers did share decision-making and often rotated the leadership among themselves.

There is no way to know the amount of gold shipped out, chiefly to China, but the fact that about 60,000 Chinese miners were at work there over about a century indicates that it must have been extremely large. As Dutch power advanced in the nineteenth century, most of the kongsis made their peace with it through a system of indirect rule, but the strongest Montrado kongsi remained defiant until conquered in the 1850 os. 


\section{The Chinese Tin-Mining Frontier}

A large proportion of the world's tin is concentrated in the chain of hills from eastern Burma in the north down through the Malayan Peninsula to the islands of Bangka and Belitung in the south. By the tenth century, the Peninsula was supplying most of Asia's tin needs. The trade boom of 15801640 witnessed a great increase in mining of this tin to supply the busy markets of India, China, Siam, and Java. Up until the seventeenth century, it was the ports of the western coast of the Peninsula-Junk Ceylon (Phuket), Perak, and Selangor - that supplied India, while Ligor (Nakhonsithammarat), Pahang, and other ports on the eastern coast supplied most of China's needs.

The miners appear to have been long-term Peninsula residents of various ethnicities, who attended to mining when the demands of rice growing or serving their rulers' requirements permitted. Mining sites were located and supervised by a pawang (shaman) who could mediate with the spirit of the tin. Men dug the ore and earth out of flooded pits, while women separated the tin ore with their fingers. ${ }^{22}$ The method was first described in Perak by Eredia: "The earth is dug out of the mountains and placed on certain tables where the earth is dispersed by water in such a way that only the tin in the form of grains remains on the tables. It is then melted in certain clay moulds and by a process of casting is converted into ... slabs." ${ }^{23}$ The "casting" was a primitive form of smelting in which burning charcoal was mixed with the tin ore until the metal ran out into the mold. These slabs, of about twenty kilograms, were then floated down the rivers to port, where the port-ruler usually took the largest share of the profits of selling it.

Around 1500, the port-sultanate of Melaka controlled most of the tin of what is today Kedah, Perak, and Selangor, and sold most of it to passing Indian merchants to take back to their own South Asian markets. The amounts, however, appear to have been small. Pires gives figures for the tin rendered to Melaka as tribute by all the west-coast ports, which amounts to only 34 tons ( 36,000 calain), worth 1,000 cruzados. ${ }^{24}$ Estimates of total exports around 1600 vary between $100-300$ tons, mostly from Perak and Phuket. The largest estimate at the peak of the trade boom is a Dutch one of 1638 , to be taken with caution, that Perak and Kedah could each produce up to 1,000 tons $(6,000$ bahar $)$ a year. ${ }^{25}$

The Portuguese occupants of Melaka (1511-1641) had to contest the supply of tin with Muslim traders, and they lost out completely after their 
great Muslim enemy Aceh conquered the Perak and Kedah fields in 1575 . The Dutch, who in turn conquered Melaka in 1641, hoped to use the port to monopolize the supply of tin, and they were in a much stronger position to do so. The largest amount they ever succeeded in acquiring, however, was 380 tons, in 1650, and the effect of their heavy-handed "system of fixed prices, annual quotas and exclusive privileges" appears only to have been to drive the tin industry of the Peninsula into decline in the second half of the century. ${ }^{26}$

Verenigde Oostindische Compagnie (voc) attempts to force the purchase of tin at unrealistically low prices from the Malay states it could control from Melaka drove the chief centers of production northward into Siamese and Burmese territory, so that Phuket (Junk Ceylon), Takuapa, and Tavoy were supplying much of the market in the early eighteenth century. Chulia (south Indian), Bugis, Chinese, and English traders paid higher prices and took the bulk of the supply. ${ }^{27}$ The quantities remained modest (probably below 1,000 tons in total), however, until the systematic exploitation of tin discoveries on Bangka by Chinese miners in the middle of the century. China's demand for Southeast Asian tin expanded greatly during its prosperous eighteenth century, partly to make the tinfoil burnt as joss paper in offerings to the ancestors, but also for packaging the booming tea trade. ${ }^{28}$

The tin of Bangka was discovered around 1710 by Muslim Sino-Malays familiar with mines on the Peninsula. It came to the notice of Batavia in 1717 , when a pretender to the Palembang throne in exile in Bangka offered some to the Dutch in an attempt to gain their support. In 1722, the voc signed a contract with the sultan of Palembang for the delivery of all Bangka tin, and in the years $1723-1730$ deliveries averaged 175 tons a year. Production continued at this modest level by traditional Southeast Asian methods until about 1750, when a Chinese known in Bangka tradition as Un Asing began systematically importing Chinese contract workers from Guangdong with their sophisticated sluicing techniques. Production increased rapidly, so that deliveries to the voc averaged 1,037 tons a year in the 1750 s and 1,562 tons in the 1760 s. $^{29}$ Although the level of reported deliveries to the voc dropped a little thereafter, the reason appears to have been that larger proportions of Bangka tin were evading Dutch control and being bought by English, Chinese, and other traders at independent ports such as Riau. European ships alone sold 1,611 tons of Southeast Asian (chiefly Bangka) tin in Canton in 1768 and an average of 2,162 tons a year in $1771-1774 .^{30}$ Presuming that an equal amount was being imported to China by Chinese vessels or being taken by Indian and Southeast Asian consumers, Southeast Asia's 
tin production must have rivaled Cornwall's by the 1770 s. Europe, however, was slow to realize the remarkable growth of this threat from the East.

Although some of the Chinese miners of Bangka were reported in a Malay history to have been brought from Siam and Vietnam, and links with the gold-miners of Borneo cannot be ruled out, most were certainly brought in directly from Canton through an exclusively Chinese network.

Annually ... a confidential and competent Chinese agent [went] by the junk returning from Palembang to China, to invite efficient and select men. . . . The expenses of their voyage and establishment was to be defrayed by the [local capitalist] who was to be reimbursed from their first profits at the mines. . . . Until they had liquidated the obligations they thus incurred . . . they were not permitted to relinquish the labours of the mines. ${ }^{31}$

There were probably over 6,000 Chinese miners there by the 1770 s, chiefly Hakkas from the Meixian area of Guangdong. They were organized in teams (kongsi, pinyin gongsi) of about thirty men responsible to a headman representing the authority of the tikos (pinyin dage, elder brother), usually a SinoMalay trader living in Palembang and providing the capital needed to open the mine and import the labor. The kongsis were relatively egalitarian: "The whole of the labourers work on terms of equality ... while all share equally in the profits." 32

The larger units of labor and capital, as well as techniques brought from China, made possible a much higher level of technology in both mining and smelting the tin. The Chinese used a chain-pallet pump common in Chinese irrigation to clear pits of 6-10 meters depth, and to wash the soil from the ore. In smelting, they introduced a superior furnace and bellows, with specialist teams of six or more men producing a high standard of purity that gave "Bangka tin" an unrivaled reputation worldwide. ${ }^{33}$

Bangka production declined in the 1790 o because of the usual problem of insecurity. On the one hand, the essential function of the tikos in mediating between the Palembang court and Chinese miners broke down as Palembang aristocrats attempted to dominate the industry. On the other, Illanun and Malay marauders began raiding the island for tin and slaves, reducing mining communities to ruin and driving the surviving Chinese away. Production began to rise again when the British occupied Bangka, in 1812, and the restored Dutch in 1816 decided to rule the island directly. Although the miners and smelters remained Chinese, the autonomy of the kongsis was gradually replaced by a greater degree of Dutch control, even in the recruitment of 
labor from Canton. Tin production recovered rapidly, from 1,250 tons a year around 1820 to 3,000 tons in the 1830 s. ${ }^{34}$,In addition, the production of the various centers on the Peninsula totaled 2,000 tons in 1835, according to a careful survey by P. J. Begbie. ${ }^{35}$ Most of these centers, too, were worked by Chinese, with Sungei Ujong (around modern Seremban), Perak, and Trengganu the most productive. ${ }^{36}$

In the nineteenth century, industrial Europe and America surged ahead of Asia as importers of tin. Straits Settlements tin exports in the 1840 s had been distributed between India (39 percent), China (10 percent), Europe (34 percent) and the United States ( 9 percent). By 1869-1873, the proportions had shifted to India 9 percent; China 18 percent, Europe 43 percent, and the United States 28 percent. ${ }^{37}$ The reason for the shift was the manufacture of tin plate, in which rapid technical advances had been made throughout the century. Tin consumption in Britain grew from a thousand tons a year in the first decade of the century to 2,600 in the 1820 s and 5,800 in the 1840 . From being the world's major exporter of tin, Britain became a net importer in the 1850s. Europe as a whole became a major importer of the tin first of Bangka and then of the Malayan Peninsula (see table 1).

Chinese mining gradually wrought the same transformation on the rich Peninsula tin fields as it had in Bangka, though with many initial setbacks due to the lack of security. Chinese had been involved in leasing the tin fields of Phuket from the Siamese king early in the eighteenth century, and were smelting there while Malays and Thais dug for the tin. Ambitious Malay rulers must periodically have introduced Chinese to boost the existing Malay production elsewhere in the Peninsula. The Sultan of Perak adopted a Dutch suggestion in the 1770 s that he emulate the favorable Bangka experience by employing Chinese miners, finding some for the task in Dutch Melaka. The ruler of Selangor brought Chinese miners into Lukut around 1815 , and there were more than 300 there by 1834 , when fighting broke out and caused a collapse. The Penghulu of Sungei Ujong (now in Negri Sembilan) established 600 Chinese miners on the Linggi River in 1828 , making use of a large advance from Melaka merchants to whom the tin was consigned. But after a conflict over a local woman in 1830, "great numbers" of the Chinese were slaughtered and the remainder fled, their property seized by the local chiefs. ${ }^{38}$ In Perak, Chinese miners had begun work by 1818 . Each time violence broke out, new miners were induced to return a few years later. ${ }^{39}$

The uneasy cooperation between Malay rulers, Chinese financiers from the Straits Settlements, Chinese smelters, and a mixture of Malay and Chinese miners opened up the forested peninsula and attracted a variety of mi- 
Table 1 European Imports of Southeast Asian Tin, in Tons p.a.

\begin{tabular}{lcccr}
\hline & $\begin{array}{c}\text { Total tin sold } \\
\text { in Europe } \\
\text { market }\end{array}$ & $\begin{array}{c}\text { Imported from } \\
\text { Southeast } \\
\text { Asia (\%) }\end{array}$ & $\begin{array}{c}\text { Imported } \\
\text { from } \\
\text { Bangka (\%) }\end{array}$ & $\begin{array}{c}\text { Imported } \\
\text { from the } \\
\text { Peninsula (\%) }\end{array}$ \\
\hline $1831-35$ & 6,185 & $1,804(29)$ & $787(12.7)$ & $1,017(16.4)$ \\
$1836-40$ & 7,704 & $2,403(31)$ & $1,575(20.4)$ & $829(10.8)$ \\
$1841-45$ & 9,992 & $3,294(33)$ & $2,452(24.5)$ & $842(8.4)$ \\
$1846-50$ & 11,793 & $4,875(41)$ & $4,066(34.5)$ & $809(6.9)$ \\
$1851-55$ & 11,789 & $5,507(47)$ & $4,207(35.7)$ & $1,300(11.0)$ \\
$1856-60$ & 14,647 & $7,773(53)$ & $5,978(40.8)$ & $1,786(12.2)$ \\
$1861-65$ & 17,537 & $7,856(45)$ & $4,579(26.1)$ & $3,277(18.7)$ \\
$1866-70$ & 18,277 & $8,515(47)$ & $4,956(27.1)$ & $3,559(19.5)$ \\
$1871-75$ & 23,134 & $10,606(46)$ & $4,755(20.6)$ & $5,851(25.3)$ \\
\hline
\end{tabular}

Source: Calculated from Wong Lin Ken, The Malayan Tin Industry to 1914 (Tucson: University of Arizona Press, 1964), 14.

grants to it. Wong Lin Ken instances the system operated by the Dato Klana of Sungei Ujong in the 1820 s. He received an advance of $\$ 2,500$ every month from Chinese financiers in Melaka, in return for directing the tin output to them. The Dato provided supplies and opium to the Chinese kongsis that worked each mine, and also levied a monthly rent from them. He required each bangsal (shed) to provide him three bahar ( $540 \mathrm{~kg}$ ) of tin at a favorable fixed price, which he then sold to the Melaka merchants. ${ }^{40}$

In the 1840 s, production expanded rapidly in response to the increasing demand for and price of tin in Europe. New ore deposits were discovered in Lukut (in today's Negri Sembilan), along the Klang River in Selangor (including the area of modern Kuala Lumpur), at Kanching on the Selangor River, and above all at Larut in the Taiping area of Perak, where there were 5,000 Chinese miners working in 1861. Older workings in Melaka itself, in nearby Sungei Ujong, and in Phuket (southern Siam) were worked much more rigorously by Chinese miners than had been the case with the mixed and part-time labor of earlier periods. Phuket, where the ancient mines had been left to languish during the wars of the late eighteenth century and early nineteenth, revived spectacularly, to the point where Bradley claimed it had a population of 25,000 Chinese (and fewer than a thousand others) in 1870, 
Table 2 Value of Penang Trade with Siam and the Peninsula, in Thousands of Straits Dollars

\begin{tabular}{lrr}
\hline & Siam & Peninsula \\
\hline 1845 & 345 & 69 \\
1854 & n.a. & 572 \\
1864 & 2,293 & 1,466 \\
1872 & 5,669 & 4,120 \\
\hline
\end{tabular}

Source: Anthony Reid, The Contest for North Sumatra: Atjeh, the Netherlands and Britain 1858-1898 (Kuala Lumpur: Oxford University Press, 1969), 294.

producing 3,60o tons of tin per year. ${ }^{41}$ As before, it was Chinese merchants in the Straits Settlements who provided the capital and initiative for this expansion, and who persevered in finding laborers for the booming mines even when political instability and periodic massacres drove the original miners out. ${ }^{42}$

Straits Settlements exports of Peninsula tin reached 2,446 tons per annum in $1844^{-1848,3,750}$ tons per annum a decade later, and 7,919 tons per annum in 1864-1869, more than tripling in twenty years..$^{43}$ Bangka production grew much more slowly, and was overtaken by the Peninsula in the 1870 s. For Penang, trade grew in the decade after 1851 "at a greater rate than at any other period of her history," largely because it was a base for the tin of Perak and of Phuket. ${ }^{44}$ The value of Pinang's trade with Siam and the Peninsula, fueled overwhelmingly by tin, rose more than tenfold in each case (see table 2).

In the years after 1873 , Britain was drawn to intervene in the crucial tinproducing states-Perak, Selangor, Negri Sembilan, and Pahang-largely by pressure from Straits merchants, Chinese and European, to end the chaotic instability that hindered commerce there. In the years after British control, Malayan tin production continued to increase rapidly, until 1895 , as did Bangka more slowly, though stabilizing or even stagnating thereafter. ${ }^{45}$ In 1879, Malaya surpassed Cornwall and Australia to become the world's largest tin producer, and soon thereafter produced more than the rest of the world combined, a position that Southeast Asian producers retain today. Throughout that period of expansion, Chinese dominated the Malayan tin trade, whether in terms of capital, labor, or technology. Peaceful conditions 
and the beginnings of transport infrastructure helped after British intervention, but the pace of expansion on the Chinese mining frontier had been as great or greater during the thirty years before British intervention created those conditions.

The frontier levied a terrible toll on these Chinese miners. Tens of thousands arrived every year to work in the mines, and a substantial proportion of them died every year there. Many succumbed to the internal conflicts of the 1830 s through the 186 os, initially at Malay hands but later overwhelmingly through secret-society conflicts, whereby the Cantonese of the so-called five districts were mobilized by the Hai San society, and those of the "four districts" by the Ghee Hin or Triad. Many more died of diseases, including malaria, cholera, and dysentery. Figures are not available until the late 1870 , by which time the ravages of beriberi made the Perak tin fields among the most lethal frontiers anywhere. ${ }^{46}$ In the years $1879-1882$, about 3,000 Chinese died every year in the Perak tin mines alone. From the 150,000 beriberi cases treated in the hospitals and clinics of the Federated Malay States in the 188 os and 1890 os, and the assumption that only a third of total cases actually reached these clinics, a recent analyst has calculated that 100,000 miners may have died of beriberi in this period alone. ${ }^{47}$

\section{Analysis}

What was the effect of the Chinese mining frontier on the longer-term history of the region? Unquestionably, these Chinese miners brought capitalism, the global economy, and industrial-scale production techniques to areas that had previously been largely jungle. They provided some infrastructure, and survived the most dangerous disease regime before settled conditions were established. Their success made Malaya, Bangka, and West Borneo so productive and important that colonial power followed.

Reports are more mixed on the political effects. George Windsor Earl, like many other advocates of British intervention in the 186os, regarded as a great evil the "unlimited extortion" that the Chinese capitalists, who typically also controlled the secret societies and hence the labor trade, could exercise over the miners. Mary Turnbull, while citing these views, argues that "the rapid expansion of the tin trade hastened the disintegration of traditional authority in the Malay states." 48 On the other hand, Wong Lin Ken sees the authority of the fifteenth century Melaka sultanate as having well and truly disintegrated by the nineteenth century, to the point where any economic surplus local chiefs could extract was devoted to pursuing internecine conflicts rather than developing the land. ${ }^{49}$ 
In comparative terms, what was exceptional about the Chinese mining kongsis was their readiness to accept the fragile authority of established river chiefs, even including paying them substantial rents, provided their essential livelihood was not threatened. Had a male workforce of this scale entered the Peninsula under Bugis, Malay, Acehnese, Thai, or European auspices, it would immediately have changed the power balance and threatened the position of rulers. What attracted the local river chiefs, indeed, was the Chinese reputation for political docility, and for governing their own internal affairs through kongsi, secret-society, and religious means. When rival Chinese secret societies were drawn into Peninsula conflicts, they certainly exacerbated them by increasing substantially the scale of operations. However, the conflicts between the chiefs were already there, and inviting Chinese in was another weapon in the ongoing Malay struggles. In more unified political environments, as in Siam, Vietnam, or the Dutch sphere, such polarization seldom occurred.

\section{Notes}

1. Michael Montesano and Patrick Jory, eds., Thai South and Malay North: Ethnic Interactions in a Plural Peninsula (Singapore: National University of Singapore Press, 2008).

2. Charles Higham, The Bronze Age of Southeast Asia (Cambridge: Cambridge University Press, 1996). Anthony Reid, The Lands below the Winds, vol. 1 of Southeast Asia in the Age of Commerce (New Haven: Yale University Press, 1988), 106-19.

3. Paul Wheatley, "Geographical Notes on Some Commodities Involved in Sung Maritime Trade," Journal of the Malayan Branch of the Royal Asiatic Society 32.2 (1959): 117.

4. Tomé Pires, The Suma Oriental of Tomé Pires, trans. Armando Cortesão (1515; London: Hakluyt Society, 1944), 125 .

5. Tom Harrison and Stanley O'Connor, Excavations of the Prehistoric Iron Industry in West Borneo, 2 vols. (Ithaca: Cornell University Southeast Asia Program, 1969).

6. Karl Hutterer, An Archaeological Picture of a Pre-Spanish Cebuano Community (Cebu: University of San Carlos, 1973), 34-37.

7. Cited in Harrison and O'Connor, Excavations of the Prehistoric Iron Industry in West Borneo, 1:199-200.

8. Reid, The Lands below the Winds, 111.

9. Cornelis Speelman, "De Handelsrelaties van het Makassaarse rijk volgens de Notitie van Cornelis Speelman uit 1670," Nederlands historische bronnen, ed. J. Noorduyn (1670; Amsterdam: Verloren, 1983), 113.

10. Wang Dayuan, Daoyi Zhilue [Island savages, 1349], translated in W. W. Rockhill, "Notes on the Relation and Trade of China," T'oung Pao (1915), 261.

11. Zhou Daguan, The Customs of Cambodia by Chou Ta-Kuan (Zhou Daguan) (c. 1310; Bangkok: Siam Society, 1993), 69. 
12. Encyclopedië van Nederlandsch-Indië, 4 vols. (The Hague: Martinus Nijhoff, 1899-1905). 13. James Lee, "Food Supply and Population Growth in Southwest China, 1250-1850," Journal of Asian Studies 41.4 (1982): 742.

14. C. Patterson Giersch, Asian Borderlands: The Transformation of Qing China's Yunnan Frontier (Cambridge: Harvard University Press, 2006), 168.

15. Alexander Woodside, Vietnam and the Chinese Model: A Comparative Study of Nguyen and Ch'ing Civil Government in the First Half of the Nineteenth Century (Cambridge: Harvard University Press, 1971), 259-6o; Nguyen Thanh-Nha, Tableau économique du Vietnam aux XVIIe et XVIIIe siècles (Paris: Cujas, 1970), 86-9o.

16. William Dampier, Voyages and Discoveries, ed. C. Wilkinson (1699; London: Argonaut, 1931), 93; T. J. Veltman, "Geschiedenis van het landschap Pidië," Tijdschrift van het Bataviaasche Genootschap 58 (1904): 73-76.

17. Sharon Carstens, "Pulai: Memories of a Gold Mining Settlement in Ulu Kelantan," Journal of the Malayan Branch of the Royal Asiatic Society 53.1 (1980): 50-67.

18. W. A. Graham, Kelantan: A State of the Malay Peninsula: A Handbook of Information (Glasgow: James Maclehose, 1908), 101.

19. Ibid., 103.

20. Mary Somers Heidhues, Gold-diggers, Farmers, and Traders in the "Chinese Districts" of West Kalimantan, Indonesia (Ithaca: Cornell University Southeast Asia Program, 2003), 51-52. 21. Wang Tai Peng, The Origins of the Chinese Kongsi (Petaling Jaya, Malaysia: Pelanduk, 1994); Heidhues, Gold-diggers, Farmers, and Traders in the "Chinese Districts" of West Kalimantan, Indonesia, 53-68.

22. Barbara Watson Andaya, Perak, the Abode of Grace: A Study of an Eighteenth Century Malay State (Kuala Lumpur: Oxford University Press, 1979).

23. Manoel Godinho de Eredia, "Eredia's Description of Malacca, Meridional India, and Cathay," trans. J. V. Mills (1613), Journal of the Malayan Branch of the Royal Asiatic Society 8.i (1930): 235 (repr., Kuala Lumpur: Malaysian Branch of the Royal Asiatic Society, 1997). 24. Pires, The Suma Oriental of Tomé Pires, 260-61.

25. G. W. Irwin, "The Dutch and the Tin trade of Malaya in the Seventeenth Century," Studies in the Social History of China and Southeast Asia, ed. Jerome Ch'en and Nicholas Tarling (Cambridge: Cambridge University Press, 1970), 268-69.

26. Ibid., 287.

27. Dianne Lewis, Jan Compagnie in the Straits of Malacca, 1641-1795 (Athens, Ohio: Ohio University Center for International Studies, 1995); Pierre Poivre, Les Mémoires d'un voyageur, ed. L. Malleret (1747; Paris: L'Ecole Française d'Extrème Orient, 1968), 75.

28. Paul Van Dyke, The Canton Trade: Life and Enterprise on the China Coast, 1700-1845 (Hong Kong: Hong Kong University Press, 2005), 148.

29. Mary Somers Heidhues, Bangka Tin and Mentok Pepper: Chinese Settlement on an Indonesian Island (Singapore: Institute of Southeast Asian Studies, 1992), 2-9.

30. H. B. Morse, The Chronicles of the East India Company Trading to China, vol. 5 (Oxford: Clarendon; repr., Taipei: Ch'eng-Wen, 1966), 139, 155, 170.

31. M. H. Court (1821), cited in Heidhues, Bangka Tin and Mentok Pepper, 31-32. 
32. John Crawfurd, History of the Indian Archipelago: Containing an Account of the Manners, Arts, Languages, Religions, Institutions, and Commerce of Its Inhabitants, 3 vols. (Edinburgh: A. Constable, 1820), 3:454.

33. Heidhues, Bangka Tin and Mentok Pepper, 10-18; Wong Lin Ken, The Malayan Tin Industry to 1914 (Tucson: University of Arizona Press, 1965), 14-15.

34. Heidhues, Bangka Tin and Mentok Pepper, 17-37.

35. P. J. Begbie, The Malayan Peninsula (1834; Kuala Lumpur: Oxford University Press, 1967), 407-9.

36. Wong, The Malayan Tin Industry to 1914, 20.

37. Calculated from ibid., 12.

38. P. J. Begbie, The Malayan Peninsula, 407-9.

39. Heidhues, Bangka Tin and Mentok Pepper, 10; Wong, The Malayan Tin Industry to 1914, 17-20.

40. Wong, The Malayan Tin Industry to 1914, 19-20.

41. Jennifer Wayne Cushman, Family and State: The Formation of a Sino-Thai Tin-Mining Dynasty, 1997-1932 (Oxford: Oxford University Press, 1991), 8.

42. Wong, The Malayan Tin Industry to 1914, 22-27; C. M. Turnbull, The Straits Settlements, 1826-67: Indian Presidency to Crown Colony (Singapore: Oxford University Press, 1972), 298-340.

43. Wong, The Malayan Tin Industry to 1914, 12.

44. Turnbull, The Straits Settlements, 160.

45. Wong, The Malayan Tin Industry to 1914, 246-47.

46. Anthony Reid, "Early Chinese Migration into North Sumatra," Studies in the Social History of China and South-East Asia: Essays in Memory of Victor Purcell, ed. Jerome Ch'en and Nicholas Tarling (Cambridge: Cambridge University Press, 1970), 300.

47. Ho Tak Ming, "Deaths in the Mines: On the Trail of a Killer Disease," Heritage Asia 4.2 (2007): 33; Wong, The Malayan Tin Industry to 1914, 74.

48. Turnbull, The Straits Settlements, 298.

49. Wong, The Malayan Tin Industry to 1914, 21-22. 